\title{
Intellectual Property and the Tourism Industry: From ACTA Protests towards a Restrictive Interpretation of Innovation Regulations
}

\author{
Alin Speriusi-Vlad ${ }^{1}$ \\ ${ }^{1}$ Faculty of Law -West University of Timisoara, 300575 Timişoara, Bd. Eroilor nr. 9A, Romania
}

\begin{abstract}
In 2012 became reality James Boyle's desire exposed in his essay from 1997 regarding a politics of intellectual property concerning the great deal of attention that must be paid to the Intellectual Property. At that time Boyle was disappointed by the lack of attention from lawyers, scholars, legal academics and the media for the Clinton administration's proposal for copyright on the Net, a document that provided the blueprint of domestic and international regulatory efforts to expand intellectual property rights. Certainly this was not the case with ACTA where the public media forced by the private citizen's protests tried to weight both the benefits and the costs of the new protection standards brought by the new international convention. After those moments Intellectual Property regulations are no more an esoteric and arcane field, something that is only interesting and comprehensible to the practitioners in the field, but a matter of public interests like the environment which arouse the attention of all the persons. In this way we all become aware that intellectual property radiates beyond the legal frame and interferes with several aspects of our lives, including our free time and the tourism consequently.
\end{abstract}

\section{Introduction: How does intellectual property fit in the tourism sector?}

This is a very important question. At first glance, it seems that tourism has nothing to do with intellectual property. However, the tourism interferes with the intellectual property. Firstly because the tourism represents a service sector and secondly, considering the intellectual property effects on economic growth [1-2]. Indeed the tourism industry has experienced continuous growth in the service sector and, according to the World Tourism Organization, its business volume equals or even surpasses that of oil exports, food products or automobiles. Tourism, it says, has become one of the major players in international commerce, and represents, at the same time, one of the main income sources for many developing countries [3].

All the intellectual property legal mechanisms are effective in the tourism sector. For example, developing and exploiting brands is particularly appropriate to the service area and thus to the tourism sector. Also trademarks, geographical indications, certification marks, collective marks or sui generis rights or industrial designs as well as other intellectual property rights such as patents, copyrights and trade secrets which contribute development and the exploitation of a tourism brand. All the intellectual property legal entitlements which provide an exclusive right of exploitation and of preventing unauthorized third parties from benefiting from that right are amply useful for the tourism sector. The intellectual property system provides very powerful tools for strengthening the 
competitiveness of those operating within the tourism industry. The rules of the game today are no longer what they used to be. Competition is very intense and the knowledge economy rewards those who understands the importance of intangibles and their role in differentiating and adding value to products. The intellectual property system provides the structure and the tools for protecting, managing, exploiting and enforcing the rights arising from such intangibles [4].

\section{ACTA and the activism in the intellectual property}

The Anti-Counterfeiting Trade Agreement (ACTA) represents a particular point in the Intellectual Property history, considering the social protest that brought in the public attention the tensions in the Intellectual Property System. The social protests have produced several notable mobilization efforts and legal victories and a fierce public opposition that has prompted governments to step away from ratification of the treaty.

Long time before, in 1997 James Boyle was disappointed by the lack of attention from lawyers, scholars, legal academics and the media for the Clinton administration's proposal for copyright on the Net, a document that provided the blueprint of domestic and international regulatory efforts to expand intellectual property rights. He deployed that "the appearance of the Clinton administration's "White Paper" on intellectual property on the National Information Infrastructure produced almost no press reaction" [5], the public media being only concerned by the right holders position, concluding that a great deal of attention must be paid to the Intellectual Property.

The first argument set out by ACTA stipulates that the efficient implementation of intellectual property rights is essential to support economic growth in all industrial sectors, as well as worldwide. Under the appearance of this noble or, at least, innocent purpose, the Anti-Counterfeiting Trade Agreement brings a series of substantial contributions to the national standards regarding the actual means of protection of intellectual property by means of the provisions set out at section 5Enforcement of intellectual property rights in the digital environment. These provisions address the question: to what extent can the individual freedoms of either the users or the potential users be limited to protect the intellectual property?

\section{ACTA and the US Supreme Court and CJEU Case-Law}

When talking about setting up the relation between the interests protected under the intellectual property and the interests of the other persons, it is difficult to draw a line between the rationales that justify the restrictions of an exclusivity given by a legal protection status, at the community level, and the reasons that give no justifications for this aspect.

Taking into consideration the international regulations, one of the questions ACTA tries to give a relevant answer, as we have already pointed out, is how far can we go to protect the intellectual property and to what extent can the individual freedoms of the users or the potential users be limited to protect the intellectual property rights. The answer was that we can go quite far and that the interest of both the authors of intellectual works and the holders of intellectual property rights is of paramount interest compared to the individual rights, interests and freedoms of the other legal subjects. The question for which ACTA seemed to give a favorable answer for the holders of such rights has been launched again after the rejection of ratification at European Union level.

It is true that the question comes back and the answer is more likely to be unfavorable for the holders of intellectual property rights and favorable to the other participants in the civil circuit. More precisely the answer that seems to be offered in the European Parliament provides for a certain balance between holders' rights and the rights of users or potential users. This line follows the arguments of European Court of Justice in the NETLOG case-law.

The European Court of Justice restates on the $16^{\text {th }}$ of February 2012 the necessity of a balance between the interests of the holders of the intellectual property rights and the interests of all other legal subjects, invoking thus the fundamental human rights, concluding that the administrator of an online network cannot order the constant supervision of its users to prevent illegal use of audio and 
video materials because several rights, such as the commercial freedom, the right to enjoy the protection of personal data, the freedom to receive and transfer information, would be breached.

More precisely the European Court of Justice found and ascertained the following: "(...) the protection of the fundamental right to property, which includes the rights linked to intellectual property, must be balanced against the protection of other fundamental rights", "(...) the injunction to install the contested filtering system is to be regarded as not respecting the requirement that a fair balance be struck between, on the one hand, the protection of the intellectual-property right enjoyed by copyright holders, and, on the other hand, that of the freedom to conduct business enjoyed by operators such as hosting service providers", "(...) Moreover, the effects of that injunction would not be limited to the hosting service provider, as the contested filtering system may also infringe the fundamental rights of that hosting service provider's service users, namely their right to protection of their personal data and their freedom to receive or impart information, which are rights safeguarded by Articles 8 and 11 of the Charter respectively", "(...) the injunction requiring installation of the contested filtering system would involve the identification, systematic analysis and processing of information connected with the profiles created on the social network by its users. The information connected with those profiles is protected personal data because, in principle, it allows those users to be identified", "(...) the above mentioned injunction would harm the freedom of information, as it would be possible that this system fail to make a distinction between a legal and an illegal content, so that the use thereof could have as consequence the blockage of the communications consisting of legal contents. As a consequence, it is not contested that the answer to the issue regarding the legal nature of a transmission of information depends on the application of legal exceptions concerning the copyright which varies from one member state to another. Additionally, some works may be regarded, in some member states, as public works or may be subject to a free publication on the internet, publication made by their authors."

The Belgian Court of Law that referred the case to the European Court of Justice, requesting a judgment where the European Court could establish whether the EU applicable laws forbids the issue of an injunction by a national law court to an internet provider, asking the latter to implement a filtering system of the information posted by the users on its servers, filed the request for the delivery of a preliminary ruling in the trial between the "SABAM" (a management organization representing the authors, composers and editors) and the NETLOG (an internet service provider). In the light of the foregoing, the answer to the question referred is that Directives 2000/31,2001/29 and 2004/48, read together and construed in the light of the requirements stemming from the protection of the applicable fundamental rights, must be interpreted as precluding an injunction made against a hosting service provider which requires it to install the contested filtering system.

The NETLOG case-law ACTA was rejected on in the European Parliament is not singular, but rather follows a decision given in the Case C-70/10 SCARLET EXTENDED SA c/ SOCIETE BELGE DES AUTEURS, COMPOSITEURS ET EDITEURS SCRL (SABAM) by which the European Court has laid down that EU law (Directives 2000/31/EC, 2001/29/EC, 2004/48/EC, 95/46/EC, 2002/58/EC corroborated and interpreted in relation to the requirements stemming from protection of applicable fundamental rights) precludes a court order issued by a national court which requires an Internet access provider to establish a system for filtering all electronic communications traveling through its services, in particular through the use of "peer-to-peer" software, which applies indiscriminately to all its clients to prevent illegal file transfer. On this occasion, CJEU sets a landmark in the control of the balance between intellectual property rights and other fundamental rights, when recognizing that protection of intellectual property right is enshrined in the EU Charter of Fundamental Rights, but does not follow in any way either its table of contents or the Court case-law, and that such a right should be intangible and, therefore, its protection should be assured. In this decision, the European Court outweighs the importance and the need of intellectual property protection with the right to personal data protection, freedom to send and receive information, and freedom to information.

This view of the European Court was later strongly nuanced, when identifying certain cases in which primacy of intellectual property to the legitimate rights and interests of other people, users or potential users of goods and services incorporating intellectual property subsists. More specifically, it 
is about the CJEU decision of April 19, 2012 in the Cause C-461/2010 BONNIER AUDIO AB et al. c/ PERFECT COMMUNICATION SWEDEN AB where it has been essentially established that Internet service providers can provide a copyright holder with the personal data of users to identify the illegal distribution of protected works, and also the CJEU decision of March 27, 2014 in the Cause C314/2012 UPC TELEKABEL WIEN GMBH c/ CONSTANTIN FILM VERLEIH GMBH where it has been essentially established that an Internet access provider may be required to block its customers' access to a website that is detrimental to copyrights. Is this a change in the case law of CJEU based on which ACTA was rejected? A response to such a powerful question is extremely important since giving up the arguments for the decision of the European Parliament to reject ACTA would call into focus the need for such protection standards. The answer can only be negative and not change the case-law of CJEU, as proven by the fact that the 2014 judgment insists on the need of a fair balance between the fundamental rights in question, which in fact reaffirms that the holders of intellectual property rights are, at least legally, on a par position toward other participants in the economic circuit. However, a less informed reader might consider that we are facing a change in caselaw since, at least formally, in its recent decisions, CJEU ignores the case-law of NETLOG and the one underlying it, not doing formally any reference to it.

After closer inspection, we can see that CJEU nuances its old legal considerations based on factual particularity of the new cases. A common point is that the European Court makes a distinction between the need to protect in abstracto the intellectual property, on the one hand, and the need to preventively protect in concreto the intellectual property, on the other hand, following infringement of intellectual property. By its recent case-law, CJEU does nothing but reaffirm that in the second case the rights and freedoms of other participants in the economic circuit, especially beneficiaries of goods and services incorporating intellectual property, even if the first hypothesis cannot be limited, may be limited to protect the legitimate rights and interests of holders of intellectual property.

In the Bonnier Audio case law, the preliminary question addressed to CJEU by a Swedish Court, concerns the situation in which the applicant of the summons (the copyright holder) proved the existence of solid evidence to the copyright prejudice caused by the intended user. This decision comes after a series of preliminary rulings where European Union law rules have been interpreted in favor of protecting the identity of Internet users and their online privacy; unlike Bonnier Audio, they concerned situations where the Internet provider was required the large scale monitoring of users' online activities and filtering of all materials posted on social networking sites to avoid copyright infringement. This is the difference made by CJEU between an actual and a potential injury, the latter not justifying a large-scale monitoring and filtering. In the case-law of UPC Telekabel Wien, the European Court goes further by showcasing the situation justifying the implementation of preventive measures against third persons who have not committed any illegal act, and showing that a concrete infringement of intellectual property must lie behind these preventive measures. Specifically, by this decision, CJEU responds to the Supreme Court of Austria that a person who publicly posts protected objects without the consent of the copyright holder, on an Internet website, he uses the services of Internet access provider of persons accessing these objects, and that a provider such as UPC Telekabel enabling clients to gain access to protected objects publicly made available on Internet websites by a third party, is nothing more than an intermediary whose services are used for copyright infringement. Starting from this factual premise, the European Court stresses that the directive aiming to ensure the rights' holders with a high level of protection, does not require a special relationship between the person prejudicing the copyright and the intermediary against whom a summons may be brought, and also that it's not necessary to prove that the clients of the Internet access provider effectively access the protected objects publicly made available on websites by a third party, as the Directive requires for the measures taken by Member States in compliance thereof to aim not only at the cessation of infringements of copyrights and related rights, but also at their prevention.

Even if the acknowledgement of the rights on tangible properties, particularly the lands, leads to a winning for the entire community through a better exploitation thereof, the protection of intellectual works has the potential to affect and even to encourage the inventive activity.

More precisely, the acknowledgement of several rights in the field of intellectual works, even if it apparently seems to represent an inducement for the authors, does not necessarily lead to the increase 
of the quality and quantity of the production of intellectual works, comes with an adverse effect too. This may happen because of the fact that the rights in the field of intellectual property can somehow hinder not only the inventive activities through the drawbacks set in the subsequent research works [7], but also the free access to information and knowledge, including here the excessive limitation of the free circulation of intellectual works. Therefore, the protection of copyright meant to serve creativity and promote access to information turned into a real obstacle for both, particularly due to a higher protection term that can easily exceed a century.

A proper example in this case is the judgment ruled by US Supreme Court in the case of Sony Corp. of America vs. Universal City Studios, Inc., also known as the Betamax case which gives an example of setting relevant landmarks in terms of limiting the control of the holders of intellectual property rights over the new technologies which can contribute to the illegal reproduction and communication of intellectual works; these landmarks can also be enforced to the latest technologies applicable to internet [7]. In this case the judges of the US Supreme Court, criticizing the ruling of the court of first instance, in this case, the US Ninth Circuit Federal Court of Appeal, underlined that "it is extraordinary to argue that the legislation in the copyright field confers to all holders of these rights, including here the two plaintiffs, the exclusive right to distribute video recording devices VTR (Video Tape Recorders) by the simple fact that these could be used to infringe their rights". Starting from this case, we can make an analogy with the ACTA's regulation, which is intended to be the answer of the regulatory system in the field of intellectual property to the danger posed by the internet and the new piracy technologies, considering the fact that, although the new technologies pose new risks regarding the breach of the rights applicable to the field of intellectual property, they also came with tremendous benefits. For example, even if the greatest movie producers in the United States of America feared the new technology of video tape recorders can seriously affect the cinematographic industry, it was almost in no time proven that, until the implementation of the DVD technology, almost half of the cinematographic industry market was covered through distribution of video tapes; so, the disadvantages were clearly inferior to the benefits brought by this new technology that has significantly contributed to the dissemination of the cinematographic creations [7]. Even in the subsequent case-laws, i.e. A\&M Records, Inc. v. Napster, Inc. and MGM Studios, Inc. v. Grokster, Ltd., the same law courts, more precisely, the Ninth Circuit Federal Court of Appeal and the US Supreme Court of Justice, even if they seemed to go back to and amend the judgments previously delivered, they didn't; moreover, the courts insisted that the intellectual property rights should be protected in relation to the technologies that appear to be explicitly promoted among the users, in terms of copyright infringement.

\section{Conclusion: The author cannot have a natural right over his intellectual creation}

This reasoning is also applied to other rights; in reality, the author of the intellectual creation is legally entitled, from a patrimonial point of view, to enforce his right to charge and cash in amounts of money from the persons or entities that are using his work, with or without the author's agreement. The prerogatives acknowledged to the author of the intellectual creation are specific to a jus in personam instituted by the law, and consequently, the author can use such right solely in the contractual relations involving his work. If somebody uses the work without firstly obtaining the holder's agreement, he may defend his interests based on civil liability in tort. Practically, the author's patrimonial rights and the rights the other holders may exclusively be enforced at the contractual or extra-contractual levels, on the grounds of the civil liability in tort, and in both cases, we are dealing with certain jus in personam and not with jus in rem or sui generis rights. It is improper to talk about a temporary monopoly, because this would assume that, after the expiry period, this monopoly could be used upon another person, which is not the case, considering the public domain and the conditions of novelty based on which the legal protection is instituted. And even if the monopoly concept is assumed, its main feature is given by the possibility of other persons to restrain the use of the intellectual work. Furthermore, there is a characteristic that differentiates the exclusive use in the field 
of intellectual property from the use itself (usus) as an attribute of the property right, and from the prerogative of the inherent use of the property right. In the case of the creations of the mind, the use thereof is "non-rival" (as stated by James Boyle), and non-exclusive respectively. In other words, the use does not exclude the simultaneous use of the same object. There cannot be multiple and simultaneous uses of the same land, but we can definitely talk about the multiple uses of a MP3 file or an image by more than one person, as the use of such items by one person does not interfere with the use of the same intellectual creation by another person [7].

\section{Acknowledgement}

This work was supported by the strategic grant POSDRU/159/1.5/S/133255, Project ID 133255 (2014), co-financed by the European Social Fund within the Sectorial Operational Program Human Resources Development 2007 - 2013.

\section{References}

1. C. Ştefănescu, I. Petrescu, A. Munteanu, Intellectual Property in Critical Conditions, http://www.wseas.us/e-library/conferences/2011/Iasi/AEBD/AEBD-35.pdf in Proceedings of the 3rd World Multiconference on AEBD'11, Iasi, Romania, July 1-3, 2011, http://www.wseas.us/elibrary/conferences/2011/Iasi/AEBD/AEBD-00.pdf (2011)

2. M. Georgescu, S. Necula, The Impact of Information Piracy and Intellectual Property Rights on the Economic Development, http://www.wseas.us/elibrary/conferences/2013/Brasov/FARI/FARI-09.pdf, in Proceedings of the 2nd International Conference on FAA'13, Proceedings of the 2nd International Conference on RIMA'13, http://www.wseas.us/e-library/conferences/2013/Brasov/FARI/FARI-00.pdf (2013)

3. http://www.unwto.org/aboutwto/why/en/why.php?op=1

4. T. Nanayakkara, Role of Intellectual Property in Enhancing the Competitiveness of the Tourism Industry, http://www.wipo.int/export/sites/www/sme/en/documents/pdf/tourism_ip.pdf

5. J. Boyle, A politics of intellectual property: Environmentalism for the Net?, Duke Law Journal, 87-116 (1997)

6. J. Boyle, The public domain: Enclosing the commons of the mind, Yale University Press (2009)

7. R. Franceschelli, Trattato di diritto Industriale. Parte Generale, I - II, Milano: DOTT. A. Giuffre Editore (1973) 